\title{
滴下水銀奄湴に關する研究（第5報） 極大現象に及ぼす外部抵抗の影焙
}

\author{
鈴、木信 \\ （京都大學林産化學所究室）
}

\begin{abstract}
Researches on the Dropping Mercury Electrode (Part 5) The Influence of External Resistance on the Maximum Current
\end{abstract}

MAKoto SUzUKI

(Agricultural Ohemieal Institute, Faculty of Agriculture, University of Kyoto, Kyoto)

It has been ascertained that the peaks of maximum currents were shifted to the more negative value of the total applied E.M.F. with increasing external resistance. This phenomenon is due to the increased ohmic potential drop in the circuit as the external resistance is increased and the magnitude of this shift is explained by analysing the current-time curves recorded ossillographicslly during the growth of single mercury drop, that is not corresponded to $I_{m} W_{e}$ as suggested by J.J. Lingane, but to $I_{d} W_{e}$, which $I_{d}$ denotes the maximal diffusion current.

(Received June 5, 1950)

ポーラログラフの電極回路に外部抵抗を掩入した場合 極大電流の形狀か經化することは既にBrdicka,Lingane によつて指摘された。即ち外部抵抗加增寸に伴つて極大 軍流の上昇部分の頋斜は楥くなり，雷流の大いさは㳦少 し，县つ極大の頂點の位置か變化する。前者については 第 4 報に扔いて㮝討した。本報では後者についてのべ 3.

Brdiêka' は $\mathrm{H}_{\ddot{g}}$ イオンの場合に原大の頂點は外部抵 抗によつて左右さ礼ないといつている. しかるに Lin-

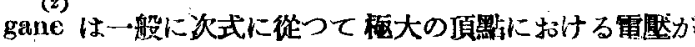
整化することを諗めた。

$$
\pi_{m}=E_{c}=E_{a}-i_{m} \cdot W_{e}
$$

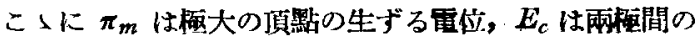

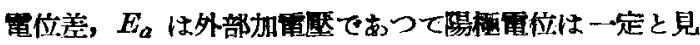
做している. 叉 $i_{m}$ は極大電滧の大いさで， $W_{e}$ は外部 抵抗を表わす。

前報で述べたように

$$
i=E_{a} \cdot \frac{4 \pi \alpha t^{1 / a}}{\rho+4 \pi \alpha W_{e^{1 / 3}}^{1 / 3}}
$$

传つて除椣電位 $\pi_{c}$ は次式の如く繁化する。

$$
\pi_{c}=E_{a} \frac{\rho}{\rho+4 \pi a W_{e} e^{1 / 3}}
$$

即ち $E_{a}$ は一定であつてす $\pi_{a}$ は滴下極 1 滴の生長期 間中に $t$ 及び $W_{e}$ によつて缽化し，その度合は $W_{e}$ の 大きい程著しい。 $W_{e}$ が可成り大きけ机ば $\pi_{c}$ は滴の生

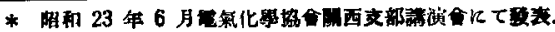

長と共に陽電位にずれて來る. 從つて $W_{e}, E_{a}$ 適䓨に 選べば $\pi_{c}$ を1滴の生長期間中に $\pi_{m}$ をはさんて隆加ら 陽に繁化させることが出來る。し板大現象が電檽雷位 によつての规规定され可逆，再現性を有なるるのであれ ばこのような場合には 1 涌の生長期間中に拱散, 極大の 兩電流が生ずべきである。電磁オッシログラフを用いて

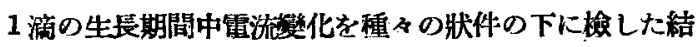
果, 我ねは Fig.1 に示才曲線を得た。これは硝酸ふ性 硝酸第一水銀, 溶液中の $\mathrm{H}_{\mathrm{H} 2}$ イオンの析出の祭の電流一

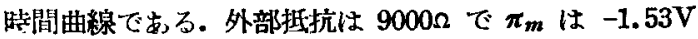
でむる. 各部加電節を $-1.40 \mathrm{~V}$ から $-1.60 \mathrm{~V}$ まで渐次 變化して行くと，最初 $E_{a}$ が $-1.40 \mathrm{~V}$ 附近では滴粒の 電位は全生長期聞中 $\pi_{m}$ より小であるから極大電流の みが生ずる. $\boldsymbol{E}_{\boldsymbol{a}}$ が增すと曲線は圖の如く 2 段となり，

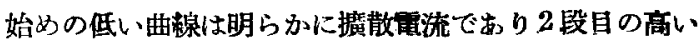
曲線は極大電流を示している. 滴の生長の初期に拁いて は $E_{a} \fallingdotseq \pi_{c}>E_{m}$ でむるから樰は分極されて撗散電流の みが生ずる. 滴が生長寸るにつれて撗散電流 $i_{d}$ は大き くなり從つて $\pi_{c}$ は (3) 式に亦す如く陽電位にずれて 來る. そして $\pi_{c}=E_{a}-i \cdot W_{e}=\pi_{m}$ なる狀熊となると電 極山突然復極されて極大電流が生ずる. $\pi_{c}=\pi_{m}$ なる狀 熊に達するには $E_{a}$ が大きい程 $i$ 從つて $t$ が大きくな $\begin{array}{cccc}E_{a}=-1.43 \mathrm{~V} & E_{a}=-1.52 \mathrm{~V} & E_{a}=-1.60 \mathrm{~V} \\ E_{a}=-1.40 \mathrm{~V} \quad E_{a}=-1.50 \mathrm{~V} & E_{a}=-1.55 \mathrm{~V}\end{array}$
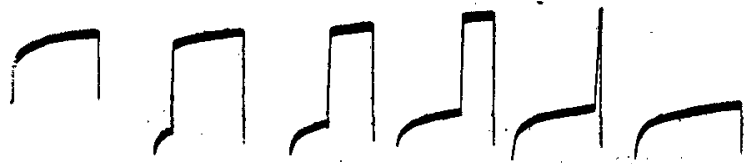

$$
\begin{gathered}
\text { Ca } 10^{-2} \mathrm{H} \mathrm{HgNO}_{3} \text { in } 5 \times 10^{-3} \mathrm{NiH}_{\mathrm{N} \mathrm{SO}_{3}} \\
W_{e}=9000 \Omega \text { Drop time }=4.2 \mathrm{sec} / \mathrm{drop} \text { at } E_{a}=0 \\
\text { Fig. } 1
\end{gathered}
$$

らなければならない。いつかえれば最初の攄散電流の部 分が長くなる.このことは Fig 1 下招いてる明らか心 示されている. 即ち外部抵抗による電壓のずれは Lingane のい $5 こ ゙ と く に i_{m} \cdot W_{e}$ ではなくて $i_{d} \cdot W_{e} て ゙$ むると考えられる。

$$
\pi_{m}=E_{a}-i_{d} \cdot W_{e}
$$

今 $\pi_{m}$ は一定と考えれば $E_{a}$ を種々に變化した場合 に一定の $W_{e}$ に椪てては $i_{d}$ の大いさは $E_{a}$ に對㕍し て變化しなければならない。第1表は $E_{a}$ と $i_{d}$ の等 化を示す。表中第 3 列は滴下時闑已撒散電流の生じてい 
る時間との此である.表中第 4 行に見るごとく $\boldsymbol{E}_{\boldsymbol{a}}$ を

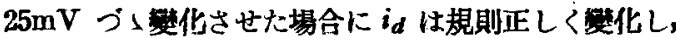
且つ $E_{a}$ が大きい程拱散電流部分の大きいことが第 3 行に宗されている。

象 1 表

加電症と $i_{d}$ と宁化

箸解渡: $10^{-2} \mathrm{nHgNO}_{3}$ in $\frac{5}{1000}$ n. $\mathrm{HNO}_{3}$

$W_{e}: 9000 \Omega$

甬流感度 : $4 \times 10^{-6} \mathrm{~A} / \mathrm{mm}$

\begin{tabular}{c|c|c|c}
\hline$E_{a}(\mathrm{~V})$ & $\begin{array}{c}\text { 谪南時间 } \\
(\mathrm{sec})\end{array}$ & 時 間 此 & $\begin{array}{c}i_{d} \\
(\mathrm{~mm})\end{array}$ \\
\hline-1.400 & 4.0 & 0.18 & 12 \\
-1.425 & 3.98 & 0.31 & 13 \\
-1.450 & 3.93 & 0.60 & 14 \\
-1.475 & 3.72 & 0.67 & 16 \\
\hline
\end{tabular}

次に $E_{a}$ 及び We を一定とし滴下時間 $t$ を紋化した 場合には抚散奄流は I1kovic 式により

$$
i_{d}=\mathrm{Km}^{2 / 3 t^{1 / 6}}
$$

$t$ を $t^{\prime}$ に篓え同一毛練管を用いれば

$$
i_{d}^{\prime}=K m^{\prime 2 / 3 t^{\prime 1 / 6}}
$$

$E_{a}$ を゙一定にとれば

$m^{2 / 3 t^{1 / 6}}=m^{2 / 3 t^{1 / 6}}$

$$
\text { 第 } 2 \text { 表 }
$$

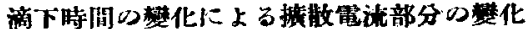

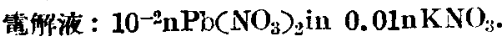

\begin{tabular}{|c|c|c|}
\hline 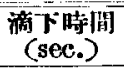 & 時间 此 & $\begin{array}{c}i_{d} \\
(\mathrm{~mm})\end{array}$ \\
\hline 4.85 & 0.21 & $\times 26.5$ \\
\hline 5.55 & 0.31 & 27.6 \\
\hline 6.50 & 0.52 & 28.0 \\
\hline
\end{tabular}
$W_{e}: 9000 \Omega$

$E_{a}:-1.50 \mathrm{~V}$

今むし $m>m^{\prime}$ とすれば $t^{\prime}>t$ となるべきである。但し $t$ は攄散軍流より柾大電流に移行する迄の時間を表わ す. 同一毛細管では $m$ と滴下時間は逆比例するから滴 下時間が大きい程時間比は大きくなるべきでむる。第2 表にはその筫驗值の 1 例字示す。

次に外部加電㡠及び滴下時間を一定とし外部抵抗を變

$$
\begin{gathered}
i_{d} \cdot W_{e}=i_{d}^{\prime} \cdot W_{e}^{\prime} \\
\therefore t^{1 / 6} W_{e}=t^{\prime 1 / 6} \cdot W_{e}^{\prime} \\
t^{1 / 6}: t^{\prime 1 / 6}=W_{e}^{\prime}: W_{e}
\end{gathered}
$$

即ち $W_{e}$ が大きくな゙れば措散奄流部分の時間比は小さ

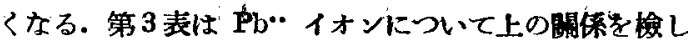

第 3 表

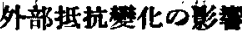

電解液： $\left.10^{-2} \mathrm{nPb}^{-} \mathrm{NO}_{2}\right)_{3}$ ino, 01nKNO 滴下時間 : 4.75sec

$E_{u}:-1.50 \mathrm{~V}$.

\begin{tabular}{c|c|c|c|c}
\hline $\begin{array}{c}W_{e} \\
(\Omega)\end{array}$ & 時間 比 & $\begin{array}{c}i_{d} \\
(\mathrm{~mm})\end{array}$ & $i_{d}$ の比 & $W_{e}$ の比 \\
\hline 7000 & 0.94 & 39 & 0.84 & 0.88 \\
8000 & 0.43 & 33 & 0.89 & 0.89 \\
9000 & 0.22 & 30 & 0.89 & 0.90 \\
\hline 10000 & 0.19 & 27 & 0.89 \\
\hline
\end{tabular}

た結果を示している. 上式より $i_{d}: i^{\prime}{ }_{d}=W_{\varepsilon}^{\prime}: W \mathrm{e}$ であ

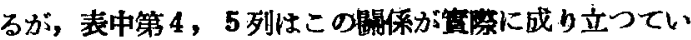
ることを示している.

一溶の成長期間中の全雷流は（2）式及び第 1 間加ら 明らかなようにWe が大きくなる程小ざくなる. 即ちボ ーラログラムに表われる梅大雷流の大いさが外部抵抗に よつて瑊少する割合は（2）式に從5のである. 又ボー ラログラムに表われる栖大の頂點は上述した所から明ら かなよらに

$$
\pi_{m}=E_{a}-I_{d} \cdot W_{e}
$$

なる條件が成立した時期に生ずる.こ〉に $\boldsymbol{I}_{d}$ は $\boldsymbol{i}_{d}$ の

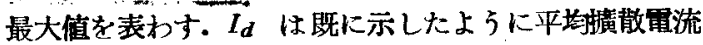
$\overline{i_{d}}$ の $7 / 6$ に相虽する。從つてポーラログラムから得た

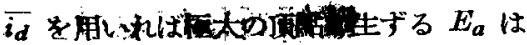

$$
E_{a}=\pi_{m}+\frac{7}{6} \cdot \overrightarrow{i_{d}} \cdot W_{e}
$$

で與えられる. 即ち外部抵抗が增すに伴つて極大の謜點 の生ずる外部加電嶎は陰にずれて行く、そしてその偏倚

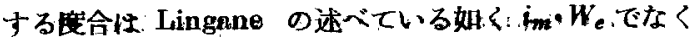

\begin{tabular}{|c|c|c|c|c|c|c|c|}
\hline$W_{e}(\Omega)$ & $\boldsymbol{E}_{m}($ Obs. $)(\mathrm{V})$ & $I_{m} \cdot W_{e}(V)$ & $E_{m}^{\prime}(\mathrm{cal})(\mathrm{V})$ & 偏美 (V) & $I_{d} \cdot W_{e}(\mathrm{~V})$ & $\begin{array}{c}E^{\prime \prime} m(\mathrm{cal}) \\
(\mathrm{V})\end{array}$ & 佩 美(V) \\
\hline 0 & 0.520 & 0 & 0.520 & 0 & 0 & 0.520 & 0 \\
\hline 1800 & 0.526 & 0.031 & 0.551 & 0.025 & 0.007 & 0.527 & $\because \quad 0.001$ \\
\hline 3600 & 0.537 & 0.069 & 0.589 & 0.052 & 0.013 & 0.533 & -0.004 \\
\hline 8100 & 0.547 . & 0.013 & 0.633 & 0.086 & 0.030 & 0.550 & 0.003 \\
\hline
\end{tabular}
て $I_{d} \cdot W_{e}$ でることは助らかである。このことはボー

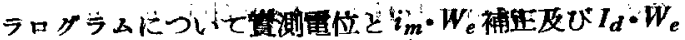

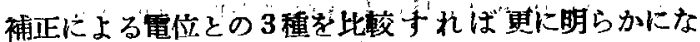
る. 第 4 表にその1例を示す。 化すれば

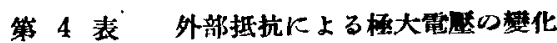

Sat. $\mathrm{O}_{2}$ in $0.001 \mathrm{n} \mathrm{KCl}$ (Upen to $\mathrm{air}$ ). $W_{\min }=20625 \Omega$ 
$10.2 \mathrm{~mol} \mathrm{Ni}\left(\mathrm{NO}_{3}\right)_{2}$ in $0.01 \mathrm{nKNO}, \mathrm{W}_{\mathrm{min}}=1013 \Omega$

\begin{tabular}{r|r|r|r|r|r|r|r}
\hline 0 & 1.400 & 0 & 1.400 & 0 & 0 & 1.400 & 0 \\
400 & 1.422 & 0.076 & 1.476 & 0.054 & 0.035 & 1.435 & 0.013 \\
900 & 1.444 & 0.139 & 1.539 & 0.095 & 0.078 & 1.478 & 0.034 \\
1800 & 1.500 & 0.249 & 1.643 & 0.143 & 0.156 & 1.556 & 0.056 \\
3600 & 1.684 & 0.434 & 1.834 & 0.150 & 0.311 & 1.711 & 0.027 \\
\hline
\end{tabular}

$7 \times 10^{-3} \mathrm{~mol}$ Nitraniline in $0.1 \mathrm{KO}+\mathrm{Buffer}$ soln. $\mathrm{pH}=3.5 \mathrm{~W}_{\min }=1340 \Omega$

\begin{tabular}{r|r|r|r|r|r|r|r}
\hline 0 & 0.633 & 0 & 0.633 & 0 & 0 & 0.633 & 0 \\
500 & 0.647 & 0.040 & 0.673 & 0.026 & 0.025 & 0.658 & 0.011 \\
1000 & 0.673 & 0.075 & 0.708 & 0.035 & 0.049 & 0.682 & 0.009 \\
2000 & 0.710 & 0.102 & 0.736 & 0.026 & 0.098 & 0.731 & 0.021 \\
3000 & 0.747 & 0.181 & 0.814 & 0.067 & 0.147 & 0.780 & 0.033 \\
\hline
\end{tabular}

第4表において $E_{m}$ は寞測值, $E^{\prime}{ }_{m}$ は $W_{e}=0$ の場 合の害測值を规难として $I_{m} \cdot W_{e}$ の值を用いて (1) 式 より計刑した槙. $E^{\prime \prime} m$ は $I_{d} \cdot W_{e}$ の值を用いて (4")

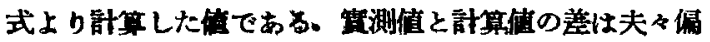
差として表わしてある. $I_{m}$ は梳の最大值であつ

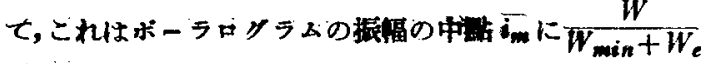
を䍪けたののである。

この表からわかる如くに $E_{m}{ }_{m}-E_{m}$ よりも $E^{n}{ }_{m}-E_{m}$

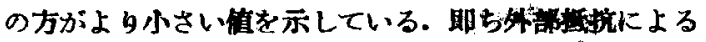
大霜原のずれいは Lingane のいう如く $i_{m} \cdot W_{e}$ による あのでなくて $I_{d} \cdot W_{e}$ によるすのであると結欱來る．
本研究は舘勇教授の御指導の下に行われたののであつ

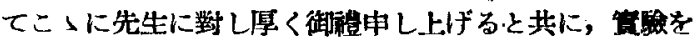

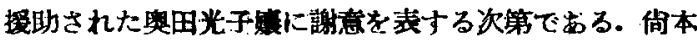

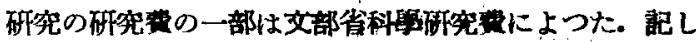
て感謝の意を表する。（昭和 25 年 6 月 5 日受理）

文㰴

(1) R. Brdicka : Collection, 8, 49 (1936).

(2) J.J. Lingane: J. Am.Chem. Soc., 62, 1665 (1940).

(3) J. Heyrovsky' and E.Vascautzanu: Collection, 3, 418 (1931)

(4) D. Ilkovie: 同諸 6, 498 (1934).

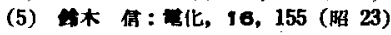

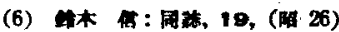

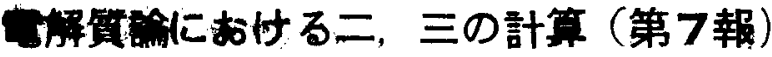

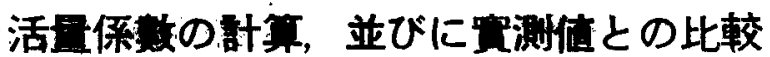

\section{中島 正夫}

Some Cakulations on the Theory of Electrolytic Surution. (Part 7)

Colculations on Activity Coefficient and the Coimpariaion with the Exporimental values.

\section{Masao Nakajima}

Let partial molar free energy of the solute be $\overline{F_{e}}$, then by the definitions,

$$
\begin{aligned}
& \overline{F_{2}}=\int_{V}^{\infty} V \frac{\partial P}{\partial V} d V+\text { const }=-\int_{V}^{\infty} V \frac{\partial^{2} W}{\partial V^{2}} d V \\
& + \text { const. }
\end{aligned}
$$

And, $\overline{F_{2}}=2 R T \ln f . \mathrm{c}+\mathrm{const} .=2 R T \ln f \cdot y+$ const. (2) Referring to Part 5, we can calculate out $f$ from (1) and (2) as follows.

$$
\ln f=\frac{y}{1-y}-\ln (1-y)-\frac{1}{2}(Y+Z)
$$

If $y \ll 1$,

$$
\ln f=2 y+\frac{3}{2} y^{2}-\frac{1}{2}(Y+Z)
$$

If the volume effect is totally neglected,

$$
\ln f=-\frac{1}{2}(Y+Z) \text {, }
$$

where $y \equiv \frac{2 N a^{3}}{1000} \mathrm{C}=0.0012[\mathrm{a}]^{3} \mathrm{C},[a] \equiv a \cdot 10^{8}$, $a$ is the mean dia. of the ions. Formulas (3)' and $(3)^{\prime \prime}$ were tested by some experimental data, and showed to be in good acord with them.

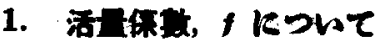

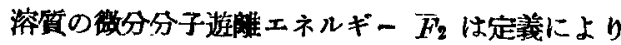

$$
\bar{F}_{2}=\int_{V}^{\infty} V-\frac{\partial P}{\partial V} d V+\text { const }=-\int_{V}^{\infty} V \frac{\partial^{2} W}{\partial V^{2}} d V+\text { const }
$$

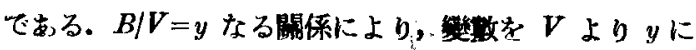

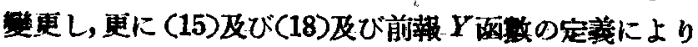

